\title{
Knowledge governance in a dynamic global context The Center for Strategic Management and Globalization at the Copenhagen Business School
}

Foss, Nicolai Juul

Document Version

Final published version

Publication date:

2007

License

CC BY-NC-ND

Citation for published version (APA):

Foss, N. J. (2007). Knowledge governance in a dynamic global context: The Center for Strategic Management and Globalization at the Copenhagen Business School. Samfundslitteratur.

Link to publication in CBS Research Portal

\section{General rights}

Copyright and moral rights for the publications made accessible in the public portal are retained by the authors and/or other copyright owners and it is a condition of accessing publications that users recognise and abide by the legal requirements associated with these rights.

\section{Take down policy}

If you believe that this document breaches copyright please contact us (research.lib@cbs.dk) providing details, and we will remove access to the work immediately and investigate your claim. 


\title{
Knowledge Governance in a Dynamic Global Context: The Center for Strategic Management and Globalization at the Copenhagen Business School
}

\author{
Nicolai J. Foss \\ SMG WP 9/2007
}

October 2007 
SMG Working Paper No. 9/2007

October 2007

ISBN: 978-87-91815-09-6

Center for Strategic Management and Globalization Copenhagen Business School

Porcelænshaven 24

2000 Frederiksberg

Denmark

www.cbs.dk/smg 


\title{
KNOWLEDGE GOVERNANCE IN A DYNAMIC GLOBAL CONTEXT: THE CENTER FOR STRATEGIC MANAGEMENT AND GLOBALIZATION AT THE COPENHAGEN BUSINESS SCHOOL
}

\author{
Nicolai J. Foss \\ Center for Strategic Management and Globalization \\ Copenhagen Business School \\ Porcelainshaven 24; 2000 Frederiksberg; Denmark \\ njf.smg@cbs.dk
}

Revised, October 16, 2007

Word count (main body): 5,473

\section{Acknowledgments}

I thank (without implicating) my SMG colleagues and Bruce Kogut for numerous comments that helped to improve this paper.

\section{Keywords}

Center for Strategic Management and Globalization, Copenhagen Business School, knowledge governance, micro-foundations, MNC organization, offshoring. 


\title{
KNOWLEDGE GOVERNANCE IN A DYNAMIC GLOBAL CONTEXT: THE CENTER FOR STRATEGIC MANAGEMENT AND GLOBALIZATION AT THE COPENHAGEN BUSINESS SCHOOL
}

\begin{abstract}
This paper tells the story of the emergence of distinct research around the theory of the firm at Copenhagen Business School within the last two decades, focussing on elements of continuity in the thinking of key CBS persons in the period. It discusses the current research agenda of the Center for Strategic Management and Globalization, a research agenda that may be described as multi-level research in international strategy, based on the economic theory of the firm and strategic management theory, and with a strong emphasis on micro-foundations and knowledge governance. The paper relates the narrative to organizational learning theory.
\end{abstract}




\section{INTRODUCTION}

How do new research groups and perspectives emerge? What is the importance of key persons? Of initial imprinting? Of combining distinct but complementary ideas? How does the organizational environment matter? These are surely key issues in the understanding of organizational learning in the context of the modern university. However, it is also a rather under-researched area in spite of its evident importance. This paper tells the story of the emergence of a distinct research stream centred around the economic theory of the firm at the Copenhagen Business School during the last two decades, and contributes to throwing light on the above questions.

Although it reaches back to the pioneering efforts of Knight (1921) and Coase (1937), the economic theory of the firm, only took off in the beginning of the 1970s in the work of particularly Williamson (1975). This takeoff coincides with the coalescing of international business as a distinct field (cf. Dunning, 1993). The IB field represent theorizing on firm organization that develops in parallel with and to some extent overlapping with developments in economics (e.g., Buckley and Casson, 1976). Strategic management takes off at about the same time (Hofer and Schendel, 1978). It, too, increasingly gives price of place to the theory of the firm, whether in a transaction cost incarnation (e.g., Rumelt, 1984) or, later, in resource- and knowledge-based manifestations (Kogut and Zander, 1992). It is usually only somewhat in retrospect that we can recognize the taking off or coalescing of important fields fields of knowledge. In the cases just mentioned, diffusion was by no means automatic. Very decent early efforts in international business were made in the UK and Sweden, beginning with Dunning's pioneering work (Dunning, 1958, 1980; Buckley and Casson, 1976), and from the beginning of the 1970s in Sweden (Glimstedt and Zander, 2007). Important early work was done on strategic management in the UK. In contrast, very few European management scholars took an interest in the economics of governance. ${ }^{1}$ In general, the European efforts in the three mentioned field were few and scattered, and more so than comparable US efforts. Taking into account the exceptions just mentioned, European research in these fields took off with a lag of about a decade relative to their US takeoff.

This brings us to the organizational unit mentioned in the sub-heading to this paper, the Center for Strategic Management and Globalization (SMG) at the Copenhagen Business

\footnotetext{
${ }^{1}$ As a piece of impressionistic evidence, Oliver Williamson spent a part of 1974 at the organization department at Copenhagen Business School. Nobody took an interest in his work. Things had changed dramatically about three decades later — Williamson was made a CBS honorary doctor in 2000.
} 
School (CBS). This unit is the main (if not the only) embodiment of a distinct perspective on international business and strategic management theory, a perspective that has developed on the basis of the economic theory of the firm for almost two decades. Thus, the scholars that constitute the SMG as well the extensive network of scholars within and outside of the CBS that is associated with the SMG are cultivating an emerging distinct perspective, called "knowledge governance." This perspective centers on the organization of knowledge processes and stresses micro-foundations and multi-level research. The SMG was only established as an independent unit at the Copenhagen Business School quite recently; specifically September 1, 2005. However, the Center grows out of a number of recent and distinct developments at one of Europe's largest and most entrepreneurial business school, in particular the change towards an entrepreneurial research-culture as well as a much increased emphasis on the "traditional" vehicles of research dissemination, that is, high-quality, peerreviewed journals. Thus, the story of the emergence of the Center and its research agenda is also to a large extent the story of the "guided evolution” (Ghoshal and Løvas, 2000) of the organization and strategy of the CBS during the last two decades, in itself constituting a lesson in knowledge governance. Of course, organizational entities only act and work through their members, so unavoidably these stories are also stories of key persons.

The following narrative weaves together these different stories. I shall focus on CBS' efforts on creating research around the study of the firm and its governance, including the many manifestations of this research in strategic management, international business, corporate governance, and knowledge management, but with particular emphasis on the SMG attempt to carve out a distinct research programme on the governance of knowledge in the context of international business. A number of implications for organizational learning in a university setting emerge from this narrative. Thus, the narrative underscores the crucial importance of key entrepreneurial persons and of their initial imprinting, that is, it emphasizes entrepreneurship in the context of path-dependence. It also underscores the importance of a context that stimulates academic entrepreneurship and allows it to take an organized form (e.g., in the form of research centers). However, the narrative also indicates that it may take a very long time for perspectives to coalesce and become articulate, even though the basic ideas may have "been there" from the beginning.

\section{BEGINNINGS, IMPRINTING, AND DISTINCTIVE PERSPECTIVES}

\section{PhD Work(s)}


I trust I can be forgiven for starting off in a somewhat ego-centric mode. I do so because my own experiences are generalizable across a $\mathrm{PhD}$ cohort that proved to be important to the evolution of research at CBS. I arrived at the CBS on October 1, 1989 as a PhD student. Two decades ago CBS presented a rather different picture from the present highly entrepreneurial, energetic, and research-oriented environment. Few seniors published in peer-reviewed journals, there was no real research culture, and therefore few or no role models. There was no course work to be done, so $\mathrm{PhD}$ students were very much left to pursue their own interests for three years. The only expectation was that one would produce a monograph, typically in Danish. Predictability, most PhD students did not finish in time. Of course, this situation of low research-intensity was by no means particular to CBS, nor was it worse than in many (most) other comparable European schools. Luckily, my arrival coincided with the arrival of the perhaps most talented $\mathrm{PhD}$ cohort in CBS history so far. Most members of the cohort eventually became full professors and/or department heads. The most prolific members of this cohort in terms of subsequent publication efforts were Torben Pedersen, Bent Petersen, Steen Thomsen, Kirsten Plichta (Foss), and the present author.

Most of the cohort members associated with a number of senior people who were quite research active, notably professors Christian Knudsen, Klaus Møller-Hansen, Jesper Strandskov, and Tore Kristensen. They were part of the first generation of Nordic management scholars to take a broad interest in economic theories of the firm. ${ }^{2}$ The reason they embraced the economics of the firm, particularly transaction cost economics, is that they took this stream as representing a sort of middle-road between the overly anonymous ideal type of the firm in neoclassical price theory (often misleadingly presented as "managerial economics”) on the one hand, and “efficiency-less”, power-oriented, and usually nonnormative sociological organization theory on the other hand (e.g., Knudsen, 1994). While the economics of the firm kept an efficiency orientation, it employed much more realistic behavioural assumptions than the basic microeconomics of the firm, and therefore connected much more naturally with management research.

This interest was clearly contagious for the cohort soon developed similar interests. PhD work was done on the economics of technological paths (Kirsten Foss, 1996a, 1996b), the organization of technological innovation (Foss, 1992, 1993), foreign direct investment

\footnotetext{
${ }^{2}$ The perhaps first Nordic management professor to actively embrace transaction cost economics and publish TCE research in top journals was Norwegian Torger Reve. See Foss (2005) for the story of the adoption of TCE in Nordic management research.
} 
(Pedersen, 1994), export through intermediaries (Petersen, 1996), and the historical evolution of the major Danish companies (Thomsen, 1992). What is common to these theses is that they all made ample use of theory of the firm perspectives, including property rights economics, transaction cost economics, and agency theory, in addition to those resource- and knowledgebased perspectives that were appearing at about this time and quickly came to dominate the strategic management and international business fields. In retrospect all the above have maintained the theory of the firm as foundational in their subsequent work.

\section{Imprinting: Circa 1988 to Circa 1995}

Since little or no course work was required, it was to a large extent up to the above cohort to imprint itself. There were obvious negative sides to this (it is difficult to learn statistics in this manner!), but also the benefits that come from the feeling of being part of an exciting emerging perspective, a certain esprit de corps. To illustrate, a number of us were literally lined up at the CBS library eagerly waiting for the arrival of the issue of the Administrative Science Quarterly that featured the now classical Williamson (1991) paper. (Obviously, this was before internet access). The conferment of the Nobel Prize to Ronald Coase in 1992 gave rise to celebrations. The discovery of the emerging resource-based view in the beginning of the 1990s was also a major event. Process approaches began to influence our thinking, whether economics contributions such as Nelson and Winter (1982) and Hayek (1945), or management approaches, such as the Uppsala internationalization model (Johansson and Vahlne, 1977). Certain articles came to be shared and central to our thinking and dialogue (e.g., Wernerfelt, 1984; Teece, 1986; Bradach and Eccles, 1989; Dierickx and Cool, 1989; Williamson, 1991; Kogut and Zander, 1992; Hennart, 1993).

Perhaps already at this time, something distinct but unifying was taking form. One component of this emerging understanding was an emphasis on process and innovation. The emphasis here was not that coming to grips with these phenomena required radical breaks with existing theory, but rather on using existing theory flexibly and on extending it where necessary. For example, Kirsten Foss (1996) showed that much technological development in industries such as the processing of vegetables and other kinds of food could be traced to attempts to reduce measurement costs (á la Barzel, 1982). Pedersen and Petersen (1998) worked on extending the internalization process model by incorporating transaction cost economics and agency theory in the model. And Thomsen (1992) looked at growth patterns in Danish industry, making use of the same perspectives. Another shared component was an emphasis on micro-perspectives, that is, on the need to take the thoughts, beliefs, preferences, 
knowledge, etc. of individuals as the analytical starting point (Coleman, 1990). There was clearly also an emerging understanding that insights in capabilities and governance ought to be combined and that attempts to separate them were misguided.

Seminar activity was initiated and brought visitors such as Sid Winter, Geoff Hodgson, Thrainn Eggertson, Brian Loasby, Howard Aldrich, and others to the School. Longer research stays at CBS by the likes of Anna Grandori, Jean-Francois Hennart, Faruk Contractor, Rosalie Tung, Anoop Madhok, and others through the 1990s were very important for shaping ideas and discussions. Imprinting also took place through external networks. Thus, Pedersen and Petersen became increasingly active in international business networks, not the least in an Nordic context ${ }^{3}$; Kirsten and I became active in new institutional economics networks; and I was one of the co-founders of the Danish Research Unit for Industrial Dynamics. Established in 1995, the DRUID, located at the CBS and dominated by CBS researchers, is mainly a conference organization and as such runs a yearly hugely successful conference on industrial dynamics, strategic management and economic geography. One such conference was a major one in 1998 on the economic theory of the firm which included Oliver Williamson, Sidney Winter, Jay Barney, Mark Casson, and many other important contributors to the field (Foss and Mahnke, 2000).

At the same time, the building up of a research culture at CBS was becoming an important strategic priority for CBS top management. Rather than adopting a uniform model imported from abroad, or dictating research initiatives from the top, CBS President Finn Junge-Jensen increasingly emphasized a bottom-up approach. In this approach, somewhat reminiscent of the famous Oticon “spaghetti organization” (Foss, 2003), local entrepreneurial research initiative would be supported, sometimes very generously, once it had passed an initial and not very rigorous screening procedure. Typically, such efforts would be organized in research center, encompassing between five and twenty scholars. At some point in time CBS had around twenty-five such centers running (it needs to be remembered that CBS has around 400 full-time faculty). A more serious evaluation would happen later; thus, selection was rather ex post than ex ante. The whole, largely successful, exercise is a prime example of "guided evolution” (Ghoshal and Løvas, 2000) in an academic context. It has also been a strategy that has been very conducive to the development of the various initiatives that eventually coalesced in the Center for Strategic Management and Globalization.

\footnotetext{
${ }^{3}$ Torben Pedersen has been very organizationally active in the Academy of International Business and has been the President of the European International Business Academy).
} 


\section{Diverging Perspectives: Circa 1995 to Circa 2000.}

Following the initial imprinting, interests diverged somewhat. Steen Thomsen moved towards an interest in corporate governance, eventually founding his own corporate governance research center at the CBS. Although Torben Pedersen also did influential work on corporate governance (Thomsen and Pedersen, 2000; Thomsen, Pedersen, and Kvist, 2006), he and Bent Petersen pursued their interests in internationalization processes (Petersen and Pedersen, 1999; Petersen and Welch, 2002) and the management of the multinational corporation, concentrating on the "centres of excellence” issue (Holm and Pedersen, 2000). Kirsten Foss cultivated a perspective that applied the economics of property rights (Barzel, 1997) to (in terms of that perspective) highly unusual areas, such as technological development (Kirsten Foss, 1996), organizational learning (Kirsten Foss, 2001), and resource value (Foss and Foss, 2005). I published a number of papers on the theory of the firm that were inspired by capabilities ideas, and developed interests in international business and the theory of science (see Foss [2008] for a compilation).

At this stage, economists George Richardson (who coined the notion of firm capabilities), Brian Loasby and Richard Langlois visited CBS several times and were important influences (Foss and Loasby, 1998; Langlois and Foss, 1999). A key theme in their research was that firm-level capabilities strongly shaped firm boundaries. This theme also became prominent in management research, particularly following Kogut and Zander (1992), who, along with other authors, extended the theme into a more general knowledge-based theory of economic organization. Thinking about these issues convinced me that crucial parts of capabilities reasoning were highly problematic. My early critical work primarily took issue with knowledge-based critiques of opportunism (Foss, 1996). However, I also became sceptical of the aggregate character of central knowledge-based constructs such as capabilities, competencies, etc. Relatedly, the black box character of arguments that asserted links between such constructs and firm-level outcomes, such as superior performance and economic organization, was highly problematic (Abell, Felin and Foss, 2007). Yet, existing economics of the firm at best paid lip service to a host of issues that were important and somehow associated with the capabilities idea, such as firm-specific communication codes, norms, practices, etc. These ideas mattered; the problem was to bring them into contact with the economics of the firm, rather than rejecting the latter. Pondering these issues gave rise to two major and well-funded research programs that placed the need to bring governance and knowledge into closer contact as a major part of their foundation. 


\section{RENEWED CONVERGENCE: KNOWLEDGE GOVERNANCE}

\section{Research Programs and Centers}

The "Learning, Incentives, and Knowledge" (LINK) program was a major grant from the Danish Social Science Research Council that involved most of the dramatis personae mentioned so far. In addition, it involved scholars who importantly contributed to the emergence of what is here described as a distinct knowledge governance perspective. Thus, Keld Laursen (e.g., Laursen and Foss, 2003; Foss and Laursen, 2005; Laursen and Salter, 2006) has explored the organizational antecedents of innovation. Thorbjørn Knudsen (e.g., Knudsen and Levinthal, 2007) has done important formal work on how organizational structure impacts the generation and evaluation of alternatives. And Lars Bo Jeppesen (Jeppesen and Frederiksen, 2006) has looked at the importance of innovation of the organization of user communities. Running from 2000 to 2004, the purpose of the program was to examine how incentives and knowledge considerations interacted to prompt and shape new organizational forms.

Highly successful in terms of publications and dissemination activity, the LINK was succeeded in 2004 by "Foundations of Knowledge Sharing: Behaviors and Governance" (FOKS), another major program sponsored by the Danish Social Science Research Council, but more focused on 1) building proper micro-foundations for knowledge sharing in organizations, and 2) for understanding how administrative machinery can actually be deployed to positively impact knowledge sharing. The FOKS project gave rise to the Center for Knowledge Governance at Copenhagen Business School which also included the international business scholar Snejina Michailova and technology management scholar Kenneth Husted (both now at the University of Auckland). More importantly, it spurred the crystallization of what is at the SMG called "knowledge governance" and it emphasized the need to build solid micro-foundations and pursue multi-level theorizing.

\section{From a Firm Focus to Micro-foundations: Research Themes}

Whereas much of the research that is discussed in this paper had a strong focus on the firm-level, much of the research in the group within the last five to 6 years has begun to examine lower levels of analysis and investigate how processes at these levels produce firm level outcomes. The status of this research above 4-5 years ago is summarized in Table 1 which contrasts "mainstream thinking" (roughly, the dominant way of thinking in the 
Academy journals and journals such as the Strategic Management Journal and the Journal of International Business Studies).

\section{Insert Table 1 Here}

The overall points in the table can be distilled from several partly overlapping research themes.

Micro-foundations of capabilities. One such line of research relates to the microfoundations of firm-level capabilities (Felin and Foss, 2005, 2006; Abell, Felin, and Foss, 2007). That this remains a seriously under-researched issue is highly problematic, as researchers and practising managers alike need to understand how capabilities emerge from individual action and interaction and how they change over time as a result of microprocesses. One way in which this may be handled is to explore how firms build knowledge about foreign markets (e.g., Petersen and Pedersen, 2002; Pedersen and Petersen, 2004).

HRM and knowledge processes. Another line of research stressed that HRM practices and systems could be deployed to further processes such as knowledge transfer and knowledge integration. For example, this was the theme of a paper by Dana Minbaeva, Torben Pedersen and colleagues (Minbaeva et al., 2003; see also Laursen and Foss, 2003; Foss and Laursen, 2005; Colombo, Delmastro, and Rabbiosi, 2007; Minbaeva, 2007), one of the most cited recent papers in the Journal of International Business Studies.

Knowledge sharing, motivation, and cognition. This line of research looks into the motivational underpinnings of knowledge sharing, drawing heavily on the psychology literature. It is closely related to the above work on HRM in an MNC context (Minbaeva, 2007). This line of research led to the recognition that for understanding knowledge-related micro-level processes, the basic economics portrayal of motivation and cognition was much too simplified and needed serious amendment. Work by and interaction with scholars like Margit Osterloh, Bruno Frey (e.g., Osterloh and Frey, 2000) and Siegwart Lindenberg (e.g., Lindenberg, 2003) has represented important impetus for this kind of work.

Managerial opportunism and new organizational forms. Research under this theme looks at problems of managerial opportunism in connection with organizational forms that are adopted in order to foster knowledge creation and stimulate knowledge sharing. Such forms 
will often involve substantial delegation of decision-making rights, but it can be argued on theoretical and empirically substantiated that it is hard for management to commit to a policy of non-intervention (Foss, 2003; Foss, Foss and Vasquez, 2006). This argument contributed to an important theme in the economics of organization, namely the "impossibility of (efficient) selective intervention” (Williamson, 1985). It also added insight into the neglected cost dimension of those new organizational forms that may be adopted to stimulate knowledgerelated benefits.

Outsourcing and offshoring. A fourth line of research emphasizes the incentive and knowledge antecedents of outsourcing and offshoring decisions, and takes a highly disaggregated perspective on international value chains. This research grows out of Bent Petersen and Torben Pedersen's interest in internationalization as a learning process (Petersen and Pedersen, 2002; Pedersen and Petersen, 2002).

Organizing knowledge flows in MNCs. A fifth theme explored how administrative machinery can be deployed in MNCs to influence knowledge transfer in desired directions (Foss and Pedersen, 2003, 2004; Minbaeva et al., 2003; Andersen, and Foss, 2005; Pedersen and Mahnke, 2004; Nielsen and Michailova, 2007). This research to a large extent emerged from a concern with centers of excellence in MNC (Holm and Pedersen, 2000), a notion that includes subsidiaries that control particularly efficient capabilities and other resources that may confer substantial bargaining power on such organizational entities. Making such subsidiaries transfer valuable capabilities may represent a distinct management problem of the knowledge governance variety.

\section{Knowledge Governance}

Several research emphases thus seemed to converge into the overall idea that processes of transferring, sharing, integrating, and creating knowledge can be governed by means of choices of not only governance structures (e.g. markets, hybrids, hierarchies), but also governance mechanisms such as authority, reward systems, standard operating procedures, ownership, etc., that is, knowledge governance. ${ }^{4}$ Of course, the basic idea has several antecedents, and contemporary like-minded allies include scholars such as Anna Grandori (Grandori, 1997, 2001), who coined the notion of knowledge governance, and Jackson Nickerson and Todd Zenger (Nickerson and Zenger, 2004). It is also closely related to the

\footnotetext{
${ }^{4}$ In hindsight it is also possible, and perhaps more correct, to tell the story the other way around: The knowledge governance has been an underlying vision under the above research efforts which are the concrete researchable manifestations of the knowledge governance idea.
} 
recent work of Nicholas Argyres, Kyle Mayer and Brian Silverman (e.g., Argyres and Mayer, 2007).

In a broad sense, an anticipation of the argument is Hayek's (1945) profound insight that societal institutions should first and foremost be assessed against the extent to which they assist in the creation of new knowledge and exploitation of existing knowledge. In terms of management, much of the "rational" organization theory of the 1960s stressed the differential capacities of alternative organizational structures. But in terms of contemporary management research, the knowledge governance theme as briefly defined above has been curiously underresearched. To be sure there has been much interest in how organization and knowledge processes relate; however, there is a lack of systematic investigation of how formal organisation impacts knowledge processes. Organisational governance as a consciously designed effort is de-emphasized, and the organisation-level antecedents that are, in fact, investigated are predominantly variables such as prior related knowledge, organisational practices, or structural conditions such as network positions, centrality, and the like.

However, the absence of formal organisation in this stream of research is somewhat worrying for a number of reasons. Managers can often more directly influence formal organisation than informal organisation. It is usually easier to change job descriptions, reward systems, etc. than to effect changes in, for example, corporate culture. Indeed, the former may drive the latter with a lag. Evidence suggests that managers do change formal organisation in an attempt to influence knowledge processes.

Cutting thematically across the fields of knowledge management, human resource management, organization theory, and strategic management, the knowledge governance approach starts from the hypothesis that knowledge processes can be influenced and directed through the deployment of governance mechanisms, in particular the formal aspects of organization that can be manipulated by management, such as organization structure, job design, reward systems, information systems, standard operating procedures, accounting systems, and other coordination mechanisms.

The knowledge governance research carried out by scholars mentioned here may be briefly described in terms akin to transaction cost economics as a sustained attempt to uncover how knowledge transactions — which differ in their characteristics - and governance mechanisms - which differs with respect to how they handle transactional problems —, are matched, using economic efficiency as the explanatory principle. Philosophically, the 
knowledge governance approach asserts the need to build micro-foundations based in individual action and interaction for organizational knowledge phenomena. It attempts to trace the specific mechanisms through which organization exerts its influence on knowledge processes (“mechanism-based explanation”, cf. Machamer, Darden, and Craver, 2000). And it has a rational(istic) twist in its approach to explanation on the scientific domain and to organization design on the managerial domain (Williamson, 1996).

In terms of intellectual underpinning, the knowledge governance approach takes much inspiration from organizational economics, but also recognizes a need to go beyond this body of thought in terms of the treatment of motivation and cognition on the level of individuals (cf. Grandori, 1997; Osterloh and Frey, 2000), how transactions are dimensionalized (cf. Nickerson and Zenger, 2004), and the set of governance mechanisms that are considered. See Table 2 for a contrast of "mainstream” thinking on knowledge in organizations and the SMG emphasis (cf. also Foss, 2007; Foss and Michailova, 2008).

\section{Insert Table 2 Here}

\section{THE CENTER FOR STRATEGIC MANAGEMENT AND GLOBALIZATION AT CBS: PRESENT SITUATION AND FUTURE PERSPECTIVES}

\section{Current Activities}

The converging research platform that united a number of CBS researchers made it appropriate to formalize the group in the form of the Center for Strategic Management and Globalization in 2005. The SMG is a well-funded research center with department status and arose as a merger of the Center for Knowledge Governance and the Center for International Sourcing. The current research platform may be described as multi-level research in international strategy, based on organizational economics and strategic management theory, and with a strong emphasis on micro-foundations and knowledge governance. The Center continues its research into knowledge governance, but has also taken a lead in the analysis of globalization and offshoring. A stream of papers on these issues is forthcoming in journals such as the Journal of International Business Studies, Management International Review, and the Journal of Management Studies. The Center is partner in the Offshoring Research 
Network, headed by Arie Lewin. These activities give rise to a very high frequency of seminars, workshops and conferences arranged by the SMG. Much of the research on knowledge governance, strategic management, and international business is carried out in close contract with the practicioner side. The SMG has a strong business advisory board that includes high-level executives from major Danish firms and the Center runs a regular and highly successful series of "business seminars,” featuring high level executives.

The SMG supplies the international research community with pro bono efforts from its members. For example, SMG researchers regularly contribute to professional development workshops and roundtables at major conferences, and deliver keynote speeches. SMG researchers participate in numerous editorial boards of journals, including top journals such as the Strategic Management Journal. Torben Pedersen is past president of the European International Business Academy, current board member of the same Academy, and current chapter chair of the Western European chapter of the Academy of International Business.

The unique profile of SMG research is clearly being increasingly recognized. SMG researchers publish in increasingly heavy journals; they have lately received numerous prizes for research excellence (including The Haynes Prize for most promising researcher on the annual meeting of the Academy of International Business, and the Sumantra Ghoshal Award for the best paper in the Business Policy and Strategy Division of the Academy of Management); citation figures are very favourable; SMG researchers contribute to important research handbooks, such as the Handbook of Entrepreneurship Research, Oxford Handbook of International Business, Handbook of Rational Choice Research, Handbook of New Institutional Economics, and Handbook of Human Capital Research.

\section{New Blood and New Directions}

In order to further expand and refine the SMG research perspectives, the Center has been joined by several fine researchers. These include Torben Andersen, who joined CBS from the George Mason University; Dana Minbaeva (e.g., Minbaeva, 2007); Bo Nielsen who joined CBS from Western Washington University (e.g., Nielsen, 2005, 2006); Christian Geisler Asmussen, a CBS PhD and a Haynes Prize recipient (e.g., Asmussen, Pedersen, and Dhanaraj, 2007); and Larissa Rabbiosi who joined from the Politecnico di Milano (e.g., Colombo, Delmastro and Rabbiosi, 2007). They have brought new competencies in multilevel modelling, mathematical modelling, econometrics, and strategic risk management that 
will contribute to bolstering and expanding SMG research. In addition, the Center is lucky to have a number of highly committed and active PhD students.

The SMG remains committed to a certain set of theoretical and methodological features or heuristics. These are an emphasis on micro-foundations, an overall economizing or efficiency perspective, an emphasis on knowledge governance, and a healthy dialogue with the economic theory of the firm. That these are not constraining is demonstrated in the expanding research agenda of SMG; see Table 3.

\section{Insert Table 3 Here}

The expansion of the SMG research agenda is partly a result of hiring new people and partly a result of extending the reach of the mentioned heuristics. Thus, SMG researchers are extending the reach of the knowledge governance approach to the understanding of alliance portfolios and further examining the role of transaction costs in the foundations of strategic management (Foss and Foss, 2007). Interest has also increasingly developed in conceptualizations of what it means to say that the MNC is a "knowledge-based entity." This involves trying to characterize the knowledge stocks and flows in a precise integrated manner, exploring how knowledge stocks constrain knowledge flows, and how the characteristics of to-be-transferred knowledge is related to the characteristics of the stocks from which they emerge (Foss and Pedersen, 2004; Mudambi, Piscitello, and Rabbiosi, 2007). This brings SMG research agenda full circle back, for the argument has been made in this paper that much of what is distinctive about that agenda emerged from dissatisfaction with knowledge-based arguments. A number of SMG researchers are also currently engaged in qualitative research in the actual management decisions that initiate internationalization processes, while others study processes of adapting governance machinery, notably HRM practices and systems. The process-oriented, qualitative research strategy that this work relies on is a welcome addition to the rather traditional cross-sectional research emphasis that has characterized the Center so far.

Other new research interests of the group go beyond the knowledge governance agenda. For example, Torben Andersen’s work on strategic risk management (e.g., Andersen, 2004; Andersen, Denrell, and Bettis, 2007) represents an important and creative contribution to the understanding of the dynamics of strategic management, and adds a novel dimension to the 
understanding of dynamic capabilities. Reflecting the general surge of interest in entrepreneurship in a number of research communities, center researchers also increasingly address entrepreneurship (e.g., Foss, Foss, Klein, and Klein, 2007), and plan to make strategic entrepreneurship and organizational innovation key research areas in the near future. Overall, these emerging interests reflect a wish to come more to grips with dynamics and process.

\section{CONCLUSION}

This brief paper has told the story of a group of researchers at the Copenhagen Business School that from the beginning of the narrative shared, not a perspective but rather an emphasis on the theory of the firm as foundational in management research, and on ideas on knowledge in organizations that derive from the strategic management and knowledge management fields. Thus, the explicit emphasis was on combining complementary ideas. This emphasis, formed in the beginning of the 1990s, has steered the group's subsequent research efforts, so that exploration has been path-dependent.

The point has also been made that their development as scholars is an important part of the story of the change of their environment, the CBS, toward a much stronger, internationally oriented research culture with a strong emphasis on bottom-up processes of local entrepreneurial initiative. In turn, the scholars discussed in this paper were instrumental in changing CBS in this way: SMG scholars have made a huge contribution to the strongly increased emphasis on high-quality research efforts at CBS, an effort that means that CBS scholars now regularly appear in the pages of top "mainstream" journals in strategic management, organization, and international business. Thus, the process was essentially coevolutionary, and was strongly stimulated by the emphasis on academic entrepreneurship that has long characterized the CBS, an emphasis that has made the CBS almost like a Hayekian extended order (Hayek, 1973) with numerous research initiatives spontaneously forming.

In spite of a gestation period of almost two decades, something resembling a distinctive view took has only really crystallized within the last five years or so. Making ideas concrete can take a very long time. Thus, it took more than a decade before the loose vision that more less implicitly organized a number of parallel research efforts became a distinct, articulate research program with an institutional embodiment in the SMG and the many CBS, national, and international scholars that in various ways are networked with the Center. 
While the CBS and SMG experience illustrates key ideas of organizational learning in a university context, it is also a somewhat idiosyncratic experience in which key persons have played an role in a specific historical phase of the evolution of a European business school. It is questionable whether there are any generalizable implications that are relevant for a major US business school that is part of a research university. However, many non-US business schools are still in a transitional phase (or only embarking upon it) where they are moving towards a stronger research orientation. For such schools, the CBS approach, stressing bottom-up processes, local entrepreneurship, an embodiment of entrepreneurial initiatives in research centers, and an emphasis on journal-based publication may be worth emulating. 


\section{REFERENCES}

Abell, Peter, Teppo Felin, and Nicolai J Foss. 2007. "Building Micro-foundations for the Routines, Capabilities, and Performance Links,” Managerial and Decision Economics (forthcoming).

Andersen, Torben J. 2004. ’Integrating Decentralized Strategy Making and Strategic Planning Processes in Dynamis Environments,” Journal of Management Studies, 41: 1271-1299.

Andersen, Torben J., Jerker Denrell, and Richard A. Bettis. 2007. "Strategic Responsiveness and Bowman’s Risk-Return Paradox,” Strategic Management Journal, 28: 407-429.

Andersen, Torben J. and Nicolai J. Foss. 2005. "Strategic Opportunity and Economic Performance in Multinational Entreprises: The Role and Effects of Information and Communication Technology,” Journal of International Management, 11: 293-310.

Argyres, Nicholas and Kyle Mayer. 2007. "Contract Design as a Firm Capability: An Integration of Learning and Transaction Cost Perspectives,” Academy of Management Review, 32: 1060-1077.

Asmussen, Christian Geisler, Torben Pedersen, and Charles Dhanaraj. 2007. "Evolution of Subsidiary Competences: Extending the Diamond Network Model,” Journal of International Business Studies (forthcoming).

Barzel, Yoram. 1982. "Measurement Costs and the Organization of Markets,” Journal of Law and Economics, 25: 27-48.

Barzel, Yoram. 1997. Economic Analysis of Property Rights, 2nd ed., Cambridge: Cambridge University Press.

Bradach, J.L. and R.G. Eccles. 1989. "Price, Authority, and Trust: From Ideal Types to Plural Forms”, Annual Review of Sociology 15: 97-118.

Buckley, Peter and Mark Casson. 1976. The Future of the Multinational Corporation. London: Macmillan.

Coase, Ronald H. 1937. “The Nature of the Firm,” Economica (N.S.) 4: 386-405.

Coleman, James S. 1990. Foundations of Social Theory. Cambridge, MA: The Belknap Press of Harvard University Press. 
Colombo, Massimo G., Marco Delmastro, and Larissa Rabbiosi. 2007. “'High Performance’ Work Practices, Decentralization and Profitability: Evidence from Panel Data”, Industrial and Corporate Change (forthcoming).

Dunning, John H. 1958. American Investment in British Manufacturing. London: Allen \& Unwin.

Dunning, John H. 1980. “Toward an Eclectic Theory of International Production,” Journal of International Business Studies, 11: 8-31.

Dunning, John H. 1993. Multinational Enterprises and the Global Economy. Workingham, UK: Addison-Wesley

Felin, Teppo and Nicolai J. Foss. 2005. "Strategic Organization: a Field in Search of Microfoundations.” Strategic Organization 3: 441-455

Foss, Kirsten. 1996a. Aspects of the Economics of Technological Paths. Ph.D Thesis. Copenhagen: Samfundslitteratur, 1996.

Foss, Kirsten. 1996b. “Transaction Costs and Technological Development,” Research Policy 25: 531-547.

Foss, Kirsten. 2001. “Organizing Technological Interdependencies: A Coordination Perspective on the Firm,” Industrial and Corporate Change 10: 151-178.

Foss, Kirsten and Nicolai J. Foss. 2005. "How Property Rights Economics Furthers the Resource-based View” Strategic Management Journal 26, 6: 541-555.

Foss, Kirsten and Nicolai J. Foss. 2007. "How Transaction Costs and Prior Knowledge Influence Opportunity Discovery: A Resource-based View,” Working Paper, Center for Strategic Management and Globalization, Copenhagen Business School.

Foss, Kirsten, Nicolai J. Foss, Peter G. Klein, and Sandra Klein. 2007. “The Entrepreneurial Organization of Heterogeneous Capital,” Journal of Management Studies (forthcoming).

Foss, Kirsten, Nicolai J. Foss, and Xosé H. Vazquez. 2006. ”Tying the Manager's Hand: Constraining Opportunistic Managerial Intervention,” Cambridge Journal of Economics, 30: 797-818.

Foss, Nicolai, 1993a. Den Økonomiske Organisering af Teknologiske Andringer. Copenhagen: Samfundslitteratur. 
Foss, Nicolai, 1993b. ”Theories of the Firm: Contractual and Competence Perspectives,” Journal of Evolutionary Economics 3: 144-160.

Foss, Nicolai J. 1996. "Knowledge-Based Approaches to the Theory of the Firm: Some Critical Comments”. Organization Science 7: 470-476.

Foss, Nicolai J. 2003. "Selective Intervention and Internal Hybrids: Interpreting and Learning from the Rise and Decline of the Oticon Spaghetti Organization.” Organization Science 14: $331-349$

Foss, Nicolai J. 2005. Strategy and Economic Organization in the Knowledge Economy. Oxford: Oxford University Press.

Foss, Nicolai J. 2007. “The Emerging Knowledge Governance Approach,” Organization, 14: 29-52.

Foss, Nicolai J. 2008. Organization, Property Rights, and Knowledge: Selected Essays of Nicolai J Foss. Edward Elgar.

Foss, Nicolai J. and Peter G. Klein. 2008. “Organizational Governance,” in Raphael Wittek, Tom Snijders, and Victor Nee, eds. The Handbook of Rational Choice Social Research. New York: Russell Sage Foundation.

Foss, Nicolai and Keld Laursen. 2005. "Performance Pay, Delegation, and Multitasking Under Uncertainty and Innovativeness: an Empirical Investigation,” Journal of Economic Behavior and Organization, 58: 246-276.

Foss, Nicolai J. and Brian J. Loasby, eds. 1998. Economic Organization, Capabilities, and Coordination: Essays in Honor of GB Richardson: London: Routledge.

Foss, Nicolai J. and Volker Mahnke, eds. 2000. Competence, Governance and Entrepreneurship. Oxford: Oxford University Press.

Foss, Nicolai J. and Snejina Michailova. 2008. Knowledge Governance: Perspectives From Different Disciplines. Oxford: Oxford University Press.

Foss, Nicolai J. and Torben Pedersen. 2003. "Transferring Knowledge in MNCs: the Role of Sources of Subsidiary Knowledge and Organizational Context," Journal of International Management, 8: 49-67.

Foss, Nicolai J. and Torben Pedersen. 2004. Special Issue on "Governing Knowledge Processes in the MNC,” Journal of International Business Studies, 25. 
Ghoshal, Sumantra and Bjørn Løvas. 2000. “Strategy as Guided Evolution,” Strategic Management Journal, 21: 875-891.

Grandori, Anna. 1997. "Governance Structures, Coordination Mechanisms and Cognitive Models,” Journal of Management and Governance, 1: 29-42.

Grandori, Anna. 2001. "Neither hierarchy nor identity: Knowledge governance mechanisms and the theory of the firm,” Journal of Management and Governance, 5: 381-399.

Hayek, Friedrich A. von. 1945. “The Use of Knowledge in Society,” in idem. Individualism and Economic Order. Chicago: University of Chicago Press.

Hayek, Friedrich A. von. 1973. Law, Legislation, and Liberty, Vol. 1: Rules and Order. Chicago: University of Chicago Press.

Hennart, Jean-Francois. 1993. "Explaining the Swollen Middle: Why Most transactions are a Mix of Market and Hierarchy," Organization Science, 4: 529-548.

Hofer, Charles and Dan Schendel. 1978. Strategy Formulation: Analytical Concepts. St. Paul: West.

Holm, Ulf and Torben Pedersen, eds. 2000. The Emergence and Impact of MNC Centres of Excellence. London: Palgrave MacMillan

Jeppesen, Lars Bo and Lars Frederiksen. 2006. "Why Do Users Contribute to Firm-Hosted User Communities?,” Organization Science 17.

Johansson, Jan and Jan-Erik Vahlne. 1977. "The Internationalization Process of the Firm,” Journal of International Business Studies, 8.

Knight, Frank H. 1921. Risk, Uncertainty, and Profit. Reprint 1965. New York: Augustus M. Kelley.

Knudsen, Christian. 1994. Økonomisk Metodologi. Copenhagen: DJØF Forlag.

Knudsen, Thorbjørn and Dan Levinthal. 2007. "Two Faces of Search: Alternative Generation and Alternative Evaluation,” Organization Science, 18: 39-54.

Kogut, Bruce and Udo Zander. 1992. "Knowledge of the Firm, Combinative Capabilities, and the Replication of Technology,” Organization Science 3: 383-397.

Langlois, Richard N. and Nicolai J. Foss. 1999. "Capabilities and Governance: The Rebirth of Production in the Theory of Economic Organization,” Kyklos, 52: 201-218. 
Laursen, Keld and Nicolai J. Foss. 2003. “New Human Resource Management Practices, Complementarities and the Impact on Innovation," Cambridge Journal of Economics, 27: 243-263.

Lindenberg, Sigward. 2003. "The Cognitive Side of Governance,” Research in the Sociology of Organizations 20: 47-76.

Machamer, P., L. Darden, and C.F. Craver. 2000. “Thinking About Mechanisms,” Philosophy of Science, 67: 1-25.

Minbaeva, Dana. 2007. “Knowledge Transfer in Multinational Corporations,” Management International Review, 47: 567-593.

Minbaeva, Dana, Torben Pedersen, Ingemar Björkman, Carl Fey, and H.J. Park. 2003. “MNC Knowledge Transfer, Subsidiary Absorptive Capacity, and HRM,” Journal of International Business Studies, 34: 586-599.

Mudambi Ram, L. Piscitello, and Larissa Rabbiosi. 2007. "Mandates and Mechanisms: Reverse Knowledge Transfer in MNEs.” Working Paper.

Nelson, Richard R. and Sidney G. Winter. 1982. An Evolutionary Theory of Economic Change. Cambridge, MA: The Belknap Press.

Nickerson, Jackson and Todd Zenger. 2004. “A Knowledge-based Theory of the Firm - The Problem-solving Perspective,” Organization Science, 15: 617-632.

Nielsen, Bo B. 2005. "The Role of Knowledge Embeddedness in the Creation of Synergies in Strategic Alliances“, Journal of Business Research, 58: 1194-1204.

Nielsen, Bo B. 2007. “Determining International Strategic Alliance Performance: A MultiDimensional Approach”, International Business Review, 16: 337-361.

Nielsen, Bo B. and Snejina Michailova. 2007. "Knowledge Management Systems in Multinational Corporations: Typology and Transitions”, Long Range Planning, 40: 314340.

Osterloh, Margit and Bruno Frey. 2000. “Motivation, Knowledge Transfer and Organizational Form,” Organization Science, 11: 538-550.

Pedersen, Torben. 1994. Danske virksomheders direkte investeringer i udlandet og udenlandske virksomheders direkte investeringer i Danmark. Copenhagen: Samfundslitteratur. 
Pedersen, Torben and Volker Mahnke, eds. 2004. Knowledge Flows, Governance, and the Multinational Enterprise. London: Palgrave MacMillan.

Pedersen, Torben and Bent Petersen. 1998. “Explaining Gradually Increasing Resource Commitment to a Foreign Market,” International Business Review, 7: 483-501

Pedersen, Torben and Bent Petersen. 2004. "Learning about Foreign Markets - Are Entrant Firms Exposed to a 'Shock Effect'?”, Journal of International Marketing, 12: 103-123.

Petersen, Bent. 1996. Explaining Cost-Effective Export Market Penetration Via Foreign Market Intermediaries. Copenhagen: Samfundslitteratur.

Petersen, Bent and Torben Pedersen. 1999. "Fast and Slow Resource Commitment to Foreign Markets - What Causes the Difference?” Journal of International Management, 5: 7391.

Bent Petersen and Torben Pedersen. 2002. “Coping with Liability of foreignness: different learning engagements of entrant firms”, Journal of International Management, 8: 339351.

Petersen, Bent and Lawrence S. Welch. 2002. "Foreign Operation Mode Combinations and Internationalisation”, Journal of Business Research, 55: 157-162.

Rumelt, R.P. 1984. “Towards a Strategic Theory of the Firm,” in C.E. Lamb, ed. Competitive Strategic Management. Englewood Cliffs: Prentice-Hall.

Teece, David J. 1986. “Profiting From Technological Innovation,” Research Policy, 15: 285305.

Thomsen, Steen. 1992. Storindustri og Transaktionsomkostninger. Copenhagen: Samfundslitteratur.

Thomsen, Steen and Torben Pedersen. 2000. "Ownership Structure and Economic Performance in the Largest European Companies,” Strategic Management Journal 21: $689-705$.

Thomsen, Steen, Torben Pedersen, and Hans Kurt Kvist. 2006. "Blockholder ownership: Effects on firm value in market and control based governance systems," Journal of Corporate Finance, 12: 246-269. 
Zander, Udo and Henrik Glimstedt. 2007. "Knowledge in International Firms and Networks: the Institute of International Business at the Stockholm School of Economics," European Management Review 3: 199-210.

Wernerfelt, Birger. 1984. “A Resource-based View of the Firm,” Strategic Management Journal, 5: 171-180.

Williamson, Oliver. 1975. Markets and Hierarchies. New York: Free Press.

Williamson, Oliver E. 1985. The Economic Institutions of Capitalism. New York: The Free Press.

Williamson, Oliver E. 1991. “Comparative Economic Organization,” Administrative Science Quarterly, 36.

Williamson, Oliver E. 1996. The Mechanisms of Governance. Oxford: Oxford University Press. 
TABLE 1: SMG: Research Emphasis

\begin{tabular}{|l|l|}
\hline \multicolumn{1}{|c|}{ “Mainstream" emphasis } & \multicolumn{1}{c|}{ SMG emphasis } \\
\hline \hline Aggregate emphasis & Micro-perspective \\
\hline Firm-level capabilities & $\begin{array}{l}\text { Understand capabilities in terms of individual skills } \\
\text { and how they are connected in architectures with other } \\
\text { assets. }\end{array}$ \\
\hline Resources & $\begin{array}{l}\text { Break down resources into their “attributes" (e.g., } \\
\text { uses, functionalities, etc.) to better understand } \\
\text { resource value and the discovery of new attributes } \\
\text { (i.e., entrepreneurship) }\end{array}$ \\
\hline $\begin{array}{l}\text { Processes of creating and deploying resources } \\
\text { blackboxed }\end{array}$ & $\begin{array}{l}\text { Process critical; knowledge creation and its } \\
\text { antecendents are highlighted. Human Resource } \\
\text { Management has an important role here. }\end{array}$ \\
\hline $\begin{array}{l}\text { Disconnect between knowledge assets and governance } \\
\text { mechanisms }\end{array}$ & $\begin{array}{l}\text { The use of governance mechanisms to foster } \\
\text { knowledge building, stimulate knowledge sharing, and } \\
\text { support knowledge integration are key issues in } \\
\text { strategic management and international business. }\end{array}$ \\
\hline
\end{tabular}


TABLE 2: Knowledge Governance

\begin{tabular}{|l|l|}
\hline \multicolumn{1}{|c|}{ "Mainstream" emphasis } & \multicolumn{1}{|c|}{ SMG emphasis } \\
\hline \hline $\begin{array}{l}\text { Much focus on aggregate knowledge variables } \\
\text { (capabilities, communities of practice, dynamic } \\
\text { capabilities, absorptive capacity, etc.). }\end{array}$ & More micro perspective, e.g., knowledge transactions. \\
\hline $\begin{array}{l}\text { Informal organization highlighted; formal } \\
\text { organization played down. }\end{array}$ & $\begin{array}{l}\text { Formal organization highlighted; complementarities } \\
\text { with informal organization with respect to impact on } \\
\text { knowledge processes need to be understood. }\end{array}$ \\
\hline Motivational and cognitive assumptions less clear. & $\begin{array}{l}\text { Crucial to investigate motivation and cognition in } \\
\text { knowledge processes. }\end{array}$ \\
\hline Disciplinary underpinning in mainly sociology. & $\begin{array}{l}\text { Disciplinary underpinning in economics, sociology, } \\
\text { and psychology. }\end{array}$ \\
\hline
\end{tabular}


TABLE 3: SMG: Future Themes

\begin{tabular}{|c|c|}
\hline Theme & Questions \\
\hline Understanding the MNC as a knowledge structure. & $\begin{array}{l}\text { - How can we rigorously conceptualize stocks } \\
\text { and flows of knowledge in the MNC } \\
\text { knowledge structure? } \\
\text { - How is subsidiary knowledge and bargaing } \\
\text { power related? }\end{array}$ \\
\hline Internationalization as a managed process & $\begin{array}{l}\text { - What is the role of managers in MNCs' } \\
\text { internalization (and externalization) } \\
\text { processes? } \\
\text { - How to manage increasingly disaggregated } \\
\text { and spatially dispersed value chain } \\
\text { activities? }\end{array}$ \\
\hline Alliance portfolio management & $\begin{array}{l}\text { - How are synergies created across } \\
\text { (international) alliances within a portfolio } \\
\text { and how does this influence evaluation of } \\
\text { portfolio performance? } \\
\text { - Are there specific alliance portfolio } \\
\text { capabilities? } \\
\text { - How to approach the multi-level issues that } \\
\text { are inherent in alliance portfolio research? }\end{array}$ \\
\hline $\begin{array}{l}\text { The process of adopting and adapting governance } \\
\text { mechanisms, such as HRM systems }\end{array}$ & $\begin{array}{l}\text { - Are there differences between the HRM } \\
\text { practices that management intends to } \\
\text { implement, the actually implemented } \\
\text { practices, and the perceived practices? What } \\
\text { explains such differences? }\end{array}$ \\
\hline $\begin{array}{l}\text { What is the role of transaction costs in the micro- } \\
\text { foundations of strategy? }\end{array}$ & $\begin{array}{l}\text { - How does the reduction of transaction costs } \\
\text { contribute to value creation? } \\
\text { - Can entrepreneurship be exercised with } \\
\text { respect to reducing transaction costs (e.g., } \\
\text { implementing new contractual designs, new } \\
\text { measurement methods etc.). } \\
\text { How does transaction costs (e.g., of internal } \\
\text { organization) influence the development of }\end{array}$ \\
\hline
\end{tabular}




\begin{tabular}{|l|l|l|}
\hline & $\begin{array}{l}\text { skills and capabilities, and how do they } \\
\text { impact technological trajectories? }\end{array}$ \\
\hline $\begin{array}{l}\text { How can we improve the understanding of } \\
\text { organizational innovation? }\end{array}$ & $\begin{array}{l}\text { What are the antecedents of organizational } \\
\text { innovations? }\end{array}$ \\
& $\begin{array}{l}\text { What are the hindrances for adopting } \\
\text { organizational innovations? }\end{array}$ \\
\hline
\end{tabular}




\section{SMG - Working Papers \\ www.cbs.dk/smg \\ 2003}

2003-1: Nicolai J. Foss, Kenneth Husted, Snejina Michailova, and Torben Pedersen: Governing Knowledge Processes: Theoretical Foundations and Research Opportunities.

2003-2: Yves Doz, Nicolai J. Foss, Stefanie Lenway, Marjorie Lyles, Silvia Massini, Thomas P. Murtha and Torben Pedersen: Future Frontiers in International Management Research: Innovation, Knowledge Creation, and Change in Multinational Companies.

2003-3: Snejina Michailova and Kate Hutchings: The Impact of In-Groups and OutGroups on Knowledge Sharing in Russia and China CKG Working Paper.

2003-4: Nicolai J. Foss and Torben Pedersen : The MNC as a Knowledge Structure: The Roles of Knowledge Sources and Organizational Instruments in MNC Knowledge Management CKG Working Paper.

2003-5: Kirsten Foss, Nicolai J. Foss and Xosé H. Vázquez-Vicente: “Tying the Manager's Hands": How Firms Can Make Credible Commitments That Make Opportunistic Managerial Intervention Less Likely CKG Working Paper.

2003-6: Marjorie Lyles, Torben Pedersen and Bent Petersen: Knowledge Gaps: The Case of Knowledge about Foreign Entry.

2003-7: Kirsten Foss and Nicolai J. Foss: The Limits to Designed Orders: Authority under "Distributed Knowledge" CKG Working Paper.

2003-8: Jens Gammelgaard and Torben Pedersen: Internal versus External Knowledge Sourcing of Subsidiaries - An Organizational Trade-Off.

2003-9: Kate Hutchings and Snejina Michailova: Facilitating Knowledge Sharing in Russian and Chinese Subsidiaries: The Importance of Groups and Personal Networks Accepted for publication in Journal of Knowledge Management.

2003-10: Volker Mahnke, Torben Pedersen and Markus Verzin: The Impact of Knowledge Management on MNC Subsidiary Performance: the Role of Absorptive Capacity CKG Working Paper.

2003-11: Tomas Hellström and Kenneth Husted: Mapping Knowledge and Intellectual Capital in Academic Environments: A Focus Group Study Accepted for publication in Journal of Intellectual Capital CKG Working Paper.

2003-12: Nicolai J Foss: Cognition and Motivation in the Theory of the Firm: Interaction or "Never the Twain Shall Meet"? Accepted for publication in Journal des Economistes et des Etudes Humaines CKG Working Paper.

2003-13: Dana Minbaeva and Snejina Michailova: Knowledge Transfer and Expatriation Practices in MNCs: The Role of Disseminative Capacity.

2003-14: Christian Vintergaard and Kenneth Husted: Enhancing Selective Capacity Through Venture Bases. 


\section{4}

2004-1: Nicolai J. Foss: Knowledge and Organization in the Theory of the Multinational Corporation: Some Foundational Issues

2004-2: Dana B. Minbaeva: HRM Practices and MNC Knowledge Transfer

2004-3: Bo Bernhard Nielsen and Snejina Michailova: Toward a Phase-Model of Global Knowledge Management Systems in Multinational Corporations

2004-4: Kirsten Foss \& Nicolai J Foss: The Next Step in the Evolution of the RBV: Integration with Transaction Cost Economics

2004-5: Teppo Felin \& Nicolai J. Foss: Methodological Individualism and the Organizational Capabilities Approach

2004-6: Jens Gammelgaard, Kenneth Husted, Snejina Michailova: Knowledge-sharing Behavior and Post-acquisition Integration Failure

2004-7: Jens Gammelgaard: Multinational Exploration of Acquired R\&D Activities

2004-8: Christoph Dörrenbächer \& Jens Gammelgaard: Subsidiary Upgrading? Strategic Inertia in the Development of German-owned Subsidiaries in Hungary

2004-9: Kirsten Foss \& Nicolai J. Foss: Resources and Transaction Costs: How the Economics of Property Rights Furthers the Resource-based View

2004-10: Jens Gammelgaard \& Thomas Ritter: The Knowledge Retrieval Matrix: Codification and Personification as Separate Strategies

2004-11: Nicolai J. Foss \& Peter G. Klein: Entrepreneurship and the Economic Theory of the Firm: Any Gains from Trade?

2004-12: Akshey Gupta \& Snejina Michailova: Knowledge Sharing in Knowledge-Intensive Firms: Opportunities and Limitations of Knowledge Codification

2004-13: Snejina Michailova \& Kate Hutchings: Knowledge Sharing and National Culture: A Comparison Between China and Russia

\section{5}

2005-1: Keld Laursen \& Ammon Salter: My Precious - The Role of Appropriability Strategies in Shaping Innovative Performance

2005-2: Nicolai J. Foss \& Peter G. Klein: The Theory of the Firm and Its Critics: A Stocktaking and Assessment

2005-3: Lars Bo Jeppesen \& Lars Frederiksen: Why Firm-Established User Communities Work for Innovation: The Personal Attributes of Innovative Users in the Case of Computer-Controlled Music

2005-4: Dana B. Minbaeva: Negative Impact of HRM Complementarity on Knowledge Transfer in MNCs

2005-5: Kirsten Foss, Nicolai J. Foss, Peter G. Klein \& Sandra K. Klein: Austrian Capital 
Theory and the Link Between Entrepreneurship and the Theory of the Firm

2005-1: Nicolai J. Foss: The Knowledge Governance Approach

2005-2: Torben J. Andersen: Capital Structure, Environmental Dynamism, Innovation Strategy, and Strategic Risk Management

2005-3: Torben J. Andersen: A Strategic Risk Management Framework for Multinational Enterprise

2005-4: Peter Holdt Christensen: Facilitating Knowledge Sharing: A Conceptual Framework

2005-5 Kirsten Foss \& Nicolai J. Foss: Hands Off! How Organizational Design Can Make Delegation Credible

2005-6 Marjorie A. Lyles, Torben Pedersen \& Bent Petersen: Closing the Knowledge Gap in Foreign Markets - A Learning Perspective

2005-7 Christian Geisler Asmussen, Torben Pedersen \& Bent Petersen: How do we Capture "Global Specialization" when Measuring Firms' Degree of internationalization?

2005-8 Kirsten Foss \& Nicolai J. Foss: Simon on Problem-Solving: Implications for New Organizational Forms

2005-9 Birgitte Grøgaard, Carmine Gioia \& Gabriel R.G. Benito: An Empirical Investigation of the Role of Industry Factors in the Internationalization Patterns of Firms

2005-10 Torben J. Andersen: The Performance and Risk Management Implications of Multinationality: An Industry Perspective

2005-11 Nicolai J. Foss: The Scientific Progress in Strategic Management: The case of the Resource-based view

2005-12 Koen H. Heimeriks: Alliance Capability as a Mediator Between Experience and Alliance Performance: An Empirical Investigation Into the Alliance Capability Development Process

2005-13 Koen H. Heimeriks, Geert Duysters \& Wim Vanhaverbeke: Developing Alliance Capabilities: An Empirical Study

2005-14 JC Spender: Management, Rational or Creative? A Knowledge-Based Discussion

\section{6}

2006-1: Nicolai J. Foss \& Peter G. Klein: The Emergence of the Modern Theory of the Firm

2006-2: Teppo Felin \& Nicolai J. Foss: Individuals and Organizations: Thoughts on a Micro-Foundations Project for Strategic Management and Organizational Analysis

2006-3: Volker Mahnke, Torben Pedersen \& Markus Venzin: Does Knowledge Sharing 
Pay? An MNC Subsidiary Perspective on Knowledge Outflows

2006-4: Torben Pedersen: Determining Factors of Subsidiary Development

2006-5 Ibuki Ishikawa: The Source of Competitive Advantage and Entrepreneurial Judgment in the RBV: Insights from the Austrian School Perspective

2006-6 Nicolai J. Foss \& Ibuki Ishikawa: Towards a Dynamic Resource-Based View: Insights from Austrian Capital and Entrepreneurship Theory

2006-7 Kirsten Foss \& Nicolai J. Foss: Entrepreneurship, Transaction Costs, and Resource Attributes

2006-8 Kirsten Foss, Nicolai J. Foss \& Peter G. Klein: Original and Derived Judgement: An Entrepreneurial Theory of Economic Organization

2006-9 Mia Reinholt: No More Polarization, Please! Towards a More Nuanced Perspective on Motivation in Organizations

2006-10 Angelika Lindstrand, Sara Melen \& Emilia Rovira: Turning social capital into business? A study of Swedish biotech firms' international expansion

2006-11 Christian Geisler Asmussen, Torben Pedersen \& Charles Dhanaraj: Evolution of Subsidiary Competences: Extending the Diamond Network Model

2006-12 John Holt, William R. Purcell, Sidney J. Gray \& Torben Pedersen: Decision Factors Influencing MNEs Regional Headquarters Location Selection Strategies

2006-13 Peter Maskell, Torben Pedersen, Bent Petersen \& Jens Dick-Nielsen: Learning Paths to Offshore Outsourcing - From Cost Reduction to Knowledge Seeking

2006-14 Christian Geisler Asmussen: Local, Regional or Global? Quantifying MNC Geographic Scope

2006-15 Christian Bjørnskov \& Nicolai J. Foss: Economic Freedom and Entrepreneurial Activity: Some Cross-Country Evidence

2006-16 Nicolai J. Foss \& Giampaolo Garzarelli: Institutions as Knowledge Capital: Ludwig M. Lachmann's Interpretative Institutionalism

2006-17 Koen H. Heimriks \& Jeffrey J. Reuer: How to Build Alliance Capabilities

2006-18 Nicolai J. Foss, Peter G. Klein, Yasemin Y. Kor \& Joseph T. Mahoney: Entrepreneurship, Subjectivism, and the Resource - Based View: Towards a New Synthesis

2006-19 Steven Globerman \& Bo B. Nielsen: Equity Versus Non-Equity International Strategic Alliances: The Role of Host Country Governance

\section{7}

2007-1 Peter Abell, Teppo Felin \& Nicolai J. Foss: Building Micro-Foundations for the Routines, Capabilities, and Performance Links 
2007-2 Michael W. Hansen, Torben Pedersen \& Bent Petersen: MNC Strategies and Linkage Effects in Developing Countries

2007-3 Niron Hashai, Christian G. Asmussen, Gabriel R.G. Benito \& Bent Petersen: Predicting the Diversity of Foreign Entry Modes

2007-4 Peter D. Ørberg Jensen \& Torben Pedersen: Whether and What to Offshore?

2007-5 Ram Mudambi \& Torben Pedersen: Agency Theory and Resource Dependency Theory: Complementary Explanations for Subsidiary Power in Multinational Corporations

2007-6 Nicolai J. Foss: Strategic Belief Management

2007-7 Nicolai J. Foss: Theory of Science Perspectives on Strategic Management Research: Debates and a Novel View

2007-8 Dana B. Minbaeva: HRM Practices and Knowledge Transfer in MNCs

2007-9 Nicolai J. Foss: Knowledge Governance in a Dynamic Global Context: The Center for Strategic Management and Globalization at the Copenhagen Business School 